\title{
Prezentacje
}

\section{Gatunek jako forma życia}

Ingrid Nelson, Shannon Gayk

TEKSTY DRUGIE 2019, NR 3, S. 168-186

DOI: $10.18318 /$ td.2019.3.11
Źródło: I. Nelson, S. Gayk

Introduction: Genre as

Form-of-Life, „Exemplaria.

Medieval, Early Modern,

Theory" 2015 No. 27:1-2,

s. 3-17. Drukza zgodą

wydawnictwa Taylor \&

Francis Ltd

www.tandfonline.com
$\mathbf{W}$ długich dziejach refleksji nad gatunkiem piśmiennictwo średniowieczne często traktowano jako wyjątek, nieciągłość bądź zakłócenie. Jak pisał Benedetto Croce w 1902 roku: „Krytycy włoskiego renesansu, pracując nad swoją poetyką w stylu Arystotelesa, zderzyli się z poezją rycerską i musieli to jak najlepiej wykorzystać"1. Hybrydyczność i zmienność średniowiecznych gatunków od dawna stanowiły wyzwanie dla nowoczesnych teorii, opartych na taksonomii - od neoklasycyzmu renesansowej poetyki po aprioryczną estetykę Kanta. O ile jednak owa niezgodność pozwala zauważyć, że gatunki są historyczne i przygodne, o tyle sama teoria też zmienia się poprzez reakcje na diachroniczne przesunięcia kulturowe. U samego Benedetta Croce odrzucenie „naukowej” abstrakcji gatunku na rzecz „estetycznej” praktyki kontemplowania konkretnego

1 B. Croce Aesthetic as Science of Expression and General Lingusitic, 2nd ed., transl. D. Ainslie, Macmillan, London 1929, s. 440.
Ingrid Nelson -historyk literatury, wykładowczyni w Amherst College. Interesuje się poezją angielską, głównie późnego średniowiecza, a także historią książki i teorią mediów. Opublikowała monografię Lyric Tactics: Poetry, Genre and Practice in Later Medieval England (2017).

\section{Shannon Gayk -}

mediewistka, wykładowczyni w Indiana University, interesuje się głównie piśmiennictwem religijnym późnego średniowiecza, poetyką, retoryką i ekokrytyką. Opublikowała monografię Image, Text, and Religious Reform in Fifteenth Century England (2010). 
dzieła opiera się na doświadczeniach genologii² ${ }^{2}$ które przekonują, że cechą tej dziedziny pozostaje ciągła oscylacja między podejmowaniem i odrzucaniem praw gatunkowych ${ }^{3}$. Ostatnie reinterpretacje teorii gatunku w różnych okresach i mediach mogą być zatem pojmowane jako reakcje na taksonomiczny synchronizm genologii z połowy stulecia, utrwalony w dziele Northropa Frye'a. Zwłaszcza odrodzenie zainteresowania twierdzeniem Derridy, że normatywna siła prawa gatunku zakłada własne zakłócenia, zaowocowało badaniami nad hybrydycznością, przygodnością i wyjątkiem jako zjawiskami centralnymi dla całej teorii ${ }^{4}$. Być może ze względu na jej długotrwałe traktowanie w kategoriach wyjątku na tle nowoczesnej genologii literatura średniowieczna zainspirowała nurt krytyki, która podkreśla społeczne i praktyczne aspekty gatunku, biorąc pod uwagę to, co Frederic Jameson nazywa „radykalną nieciągłością środków produkcji oraz ich kulturowych wyrazów"'. Zaproponowane przez krytyka Hansa Roberta Jaussa pojęcie gatunku średniowiecznego jako "horyzontu oczekiwań"6 dało początek niewielkiemu, ale dynamicznemu nurtowi krytyki, badającemu, jak gatunki tworzą - i jak są tworzone przez - społeczne struktury, konteksty użycia i wartości użytkowe?.

2 Autorki posługują się na ogół formułą genre theory, ale ze względów stylistycznych niekiedy zastępuję ją utrwalonym w polszczyźnie terminem genologia [przyp. tłum.].

3 Tamże, s. 32-38, 449-458.

4 Spośród prac krytycznych inspirowanych przełomowym esejem ). Derridy (The Law of Genre, trans. A. Ronell, "Critical Inquiry” 1980 Vol. 7, No. 1) zob. np. W. Dimock Through Other Continents: American Literature Across Deep Time, Princeton University Press, Princeton 2006.

5 F. Jameson The Polictical Unconscious: Narrative as Socially Symbolic Act, Cornell University Press, Ithaca 1982, s. 130.

6 Zob. H.R. Jauss Historia literatury jako prowokacja, przeł. M. Łukasiewicz, Wydawnictwo IBL PAN, Warszawa 1999.

7 Zob. A. Butterfield Medieval Genres and Modern Genre Theory " Paragraph" 1990 No. 13; J. Orlemanski Genre, w: Handbook of Middle English Studies, ed. by M. Turner, Wiley-Blackwell, Malden 2013. Bardziej taksonomiczne podejście do problematyki gatunków średniowiecznych można znaleźć w pracach P. Strohma: The Origin and Meaning of Middle English Romance , "Genre" 1977 No. 10 i Middle English Narrative Genres, "Genre" 1980 No. 13. Część badaczy pokazuje, jak normatywna siła "praw” gatunkowej taksonomi przecina kulturowe normy płci kulturowej i seksualności, np.: S. Crane Gender and Romance in Chaucer's Canterbury Tales, Princeton University Press, Princeton 1994; S. Gaunt Gender and Genre in Medieval French Literature, Cambridge University Press, Cambridge 1995; T. Pugh Queering Medieval Genres, Palgrave Macmillan, New York 2004. Z kolei A. Hiatt próbuje przełamać systemowe taksonomie gatunkowe, ale podtrzymuje zainteresowanie nomenklaturą, zauważając, że o ile "teksty pisane nie wytworzyły 
W odpowiedzi na poststrukturalistyczne krytyki „prawa” gatunku proponujemy więc rozważenie "reguły” gatunkowej. W analizie Derridy "prawo” stoi ponad i poza praktyką nie tyle jako „obowiązkowy przymus”, ile raczej „dyskurs”, który „działa na granicy” między faktyczną swobodą działania podmiotu a jego podporządkowaniem zakazującemu prawu ${ }^{8}$. W swoim omówieniu klasztornego życia benedyktynów Giorgio Agamben wprowadza zamiast „prawa” pojęcie „reguły”. W odróżnieniu od jurystycznej struktury „prawa”, kierującego nowoczesnym życiem pod suwerenną władzą, liturgiczna struktura „zwykłego życia” (koinos bios, od czego pochodzi termin cenobia - klasztor) jest regułą: „normą, która nie odnosi się do pojedynczych czynności ani zdarzeń, ale do całego życia jednostki"9. Prowadzone przez liturgię, reguła i życie łączą się w praktyce klasztornej, by utworzyć to, co Agamben nazywa „formą życia” (forma vitae), pożyczając termin od Wittgensteina ${ }^{\mathbf{1 0}}$. Forma życia sugeruje, że jest ono praktykowane, interpretowane i kierowane przez formy, a więc reguły bądź normy są współtwórcze z żywym doświadczeniem. Forma życia zachowuje także potencjalność całego życia ludzkiego, niezależnie od miejsca zajmowanego przez podmiot w strukturach prawnych bądź administracyjnych:

Życie, którego nie można oddzielić od jego formy jest życiem, dla którego stawkę danego sposobu życia stanowi właśnie samo życie. Co znaczy to sformułowanie? Charakteryzuje ono życie - ludzkie życie - w którym poszczególne sposoby, czynności i procesy życiowe nigdy nie są po

własnej nomenklatury generycznej", to $w$ dostosowywaniu pojęć ze sztuk performatywnych „wskazują na tendencję tekstów literackich do destabilizowania istniejących struktur systemowych" (tegoż Genre Without System, w: Oxford Twenty-First Century Approaches to Literature: Middle English, ed. by P. Strohm, Oxford University Press, Oxford 2007, s. 280). Spoza obszaru mediewistyki należy wskazać takie prace poświęcone społecznym i kulturowym aspektom gatunku jak np. F. Jameson The Polictical Unconscious...; M. Bachtin Problem gatunków mowy, w: Estetyka twórczości słownej, przeł. D. Ulicka, oprac. i wstęp. E. Czaplejewicz, PIW, Warszawa 1986; C. Miller Genre as Social Action, "Quarterly Journal of Speech" 1984 No. 70; The Rhetoric and Ideology of Genre:Strategies for Stability and Change, ed. by R. Coe i in., Hampton Press, Cresskill 2002; J. Frow Genre, Routledge, London-New York 2006.

8 J. Derrida Przed Prawem, przeł. J. Gutorow, w: Teorie literatury XX wieku. Antologia, red. A. Burzyńska, M.P. Markowski, Znak, Kraków 2006, s. 429.

9 G. Agamben The Highest Poverty. Monastic Rules and Form-of-Life, transl. A. Kotsko, Stanford University Press, Stanford 2013, S. 26.

10 Tamże, s. xii. 
prostu faktami, ale zawsze i przede wszystkim możliwościami życia [wyróż. w oryg.] $]^{11}$

Kiedy życie łączy się z regułą, unika bycia jedynie przedmiotem prawa. Zasadniczo przed-nowoczesna w swej koncepcji forma życia stawia opór nowoczesnym formom politycznego ucisku poprzez łączenie teorii oraz praktyki, tekstu i żywego doświadczenia. Forma życia obiecuje życie „które nigdy nie jest dane jako własność, lecz tylko jako powszechny użytek".12

Tekstowe przejawy form życia nigdzie nie ujawniają się jaśniej niż w przednowoczesnym piśmiennictwie, a zwłaszcza w wielojęzycznych i transkulturowych tekstach z średniowiecznej Anglii. W realizacjach ówczesnej liturgii i zastosowaniach zakonnych reguł, jak wykazuje Agamben, „pisanie i życie, bycie i życie stają się właściwie nierozdzielne w formie całkowitej liturgizacji życia oraz ożywienia liturgii, stanowiącej również swoistą pełnię"13. Podobnie w średniowiecznej hagiografii, żywe doświadczenie świętego i zapisane świadectwo są często wymienne, powiązane semantycznie, gdzie vita świętego pozostaje zarazem formą i treścią, zarówno czymś napisanym i czymś przeżytym. Również gatunki świeckie wiążą formę i życie. Jak pokazuje wielu autorów, gatunki tak różne jak przysłowia (Bradbury), encyklopedie (Steiner), traktaty o dobrym wychowaniu (Jahner) nie tylko oddają żywe doświadczenie swoich czytelników, ale nastawione są również na to, by je kształtować. Podczas gdy np. zwierciadło (fürstenspiegel) - jak pokazuje M. Giancarlo - odbija obraz tego, co ma wytworzyć (dobrze zorganizowanego władcy), to średniowieczne romanse (Gilbert) zachęcają do lektury, która włącza w swój zakres zarówno kwestie gatunkowe, jak i egzystencjalne i etyczne postawy ${ }^{14}$.

G. Agamben Means without Ends: Notes on Politics, transl. V. Binetti, C. Casarino, University of Minnesota, Minneapolis 2000, s. 4.

G. Agamben The Highest Poverty..., s. xiii.

Tamże, s. 82.

14 Autorki przywołują tu kolejne szkice opublikowane w numerze tematycznym "Exemplaria” 2015 Vol. 27, No. 1/2: N.M. Bradbury The Proverb as Embedded Microgenre in Chaucer and The Dialogue of Solomon and Marcolf; E. Steiner Compendious Genres: Higden, Trevisa, and the Medieval Encyclopedia; J. Jahner Reading for the End: Prescriptive Writing and the Practice of Genre; M. Giancarlo Mirror, Mirror: Princely Hermeneutics, Practical Constitutionalism, and the Genres of the English Fürstenspiegel; ). Gilbert Genus and Genre: The Old French Verse Roman d'Alexandre, Alexander and Dindimus. 
W niektórych pracach (Chaganti, Johnson ${ }^{15}$ ) widać, że gatunki zyskują istnienie w użyciu, a takie formy jak liryka (co swego czasu pokazywała Ardis Butterfield) zachowują „żywą formę", z „całym obszarem życia poza stronicą, poza rejestrem, jako swobodnie dryfujący zestaw elementów pamięciowych, z możliwością przejściowej konkretyzacji formalnej na stronie"16. Jak więc przekonują wspomniane prace, w przednowoczesnych tekstach żywe doświadczenie i zapisana forma są dla siebie wzajemnie konstytutywne.

Nie wystarczy jednak, powiedzieć, że średniowieczne teksty działają jako formae vitae, że łączą formę i życie, aby wyjaśnić, jak z tego skrzyżowania wyłania się gatunek. Z jednej strony przednowoczesna literatura i teoria literatury sugerują, że ustalenie, co czyni gatunek swoistą formą życia, jest ważniejsze od zdefiniowania, czym jest gatunek. Z drugiej wszakże - choć średniowieczne teksty rzadko mówią o gatunku jako takim, to przejawiają jasną świadomość właściwych mu konwencji, form i taksonomii, nawet jeśli przedstawiają go jako byt zasadniczo dynamiczny, performatywny i uczestniczący. Przesunięcie w naszym pojmowaniu średniowiecznego gatunku od "prawa” do „reguły” pozwala oddać szczególnie praktyczne nacechowanie ówczesnego myślenia gatunkowego. Nieszczelna granica między tekstem a życiem przejawia się jako gatunek, bo choć nie wszystkie wypowiedzi są formami życia, to średniowieczne odmiany tekstowe działają dokładnie jako reguły w rozumieniu Agambena, nadając kształt praktyce, która musi zostać odegrana (performed), aby stać się formą życia. Proponowane przez nas modele gatunku w mniejszym stopniu zakładają Derridiańskie zerwanie niż ciągłość czy negocjację między praktyką a normą. Właśnie dlatego że teksty średniowieczne tak często czynią przejrzystymi swoje zastosowania i konteksty użycia, wyraźnie uruchamiając dialektykę między formą a życiem, mogą być szczególnie pouczające dla teoretycznych ujęć gatunku w późniejszych epokach. Teksty średniowieczne miały być przede wszystkim używane: dla rozrywki, umoralnienia bądź przekazania praktycznej wiedzy. Przywołując pamiętne określenie Christophera Cannona „forma jest tym, co wspólne dla myśli i rzeczy", moglibyśmy powiedzieć, że gatunek jest tym, co myśl i życie

S. Chaganti Dance in a Haunted Space: Genre, Form, and the Middle English Carol; E. Johnson Horrific Visions of the Host: A Meditation on Genre, tamże.

A. Butterfield The Construction of Textual Form: Cross-Lingual Citation in the Medieval Insular Lyric, w: Citation, Intertextuality and Memory in the Middle Ages and Renaissance 1: Text, Music and Image from Macahut to Ariosto, ed. by Y. Plumley, G. Di Bacco, S. Jossa, University of Exeter P, Exeter 2011, s. 57. 
- jako doświadczenie, jako praktyka - mają ze sobą wspólnego"17. Gatunek, zarówno w swojej teorii, jak i w zastosowaniu, jest więc zawsze powiązany z tym, co teoretycy mediów określają jako „świat życia”, co zaś obejmuje czasowe, przestrzenne, a nawet wirtualne sfery żywego doświadczenia ${ }^{18}$.

Weźmy dla przykładu poemat średniowieczny, w którym rozmnożenie gatunków i produkcja „światów życia” ma zasadnicze znaczenie dla ujęcia relacji między regułą a życiem: Widzenie o Piotrze Oraczu Williama Langlan$\mathrm{da}^{19}$, dzieło uznane za „samoświadome odtworzenie gatunku"20, jak też naznaczone przez „zmienne odniesienia gatunkowe"21. Zadłużony wobec nauk scholastycznych, gatunków dworskich i dewocyjnych oraz liturgii, poemat wpisuje tę zróżnicowaną gatunkowo produkcję (makynge) w obręb formy życia; zarówno angażuje, jak i stara się tworzyć „światy życia”. Zwłaszcza ostatni passus poematu (przez wczesnych skrybów nazywany czasem vita) podąża za marzycielem, Willem, gdy ten stara się zrozumieć i określić trzy formy życia: Dowel („Do-Well” - „Czyń-Dobrze”), Dobet („Do-Better” - „Czyń-Lepiej”) i Dobest („Do-Best” - „Czyń-Najlepiej”). Jak zauważa Emily Steiner, trójca ta „obejmuje związek między byciem i robieniem... i utrzymuje możliwość idealnej formy, łączącej praktykę moralną i literacką"22. Dla pewności, zbieżność formy i praktyki pozostaje kluczową kwestią w centralnych wizjach poematu, ujawniającą się, gdy Will usiłuje zrozumieć stosunek formy i życia, literackiego i doświadczonego. W początkowych wersach passus XII wersji B Ymaginatif ostrzega Willa przed duchową jałowością twórczości literackiej (XII.16-18).Tworzenie książek, przekonuje Ymaginatif, nie jest tak skuteczne, jak praktyka modlitewna. Przy okazji omówienia takich niepokojów co do „tworzenia” w Piotrze Oraczu Anne Middleton przekonuje, że owe momenty tworzą „bardzo spójną, choć implicytną, definicję gatunku, która poddaje

Ch. Cannon The Grounds of English Literature, Oxford University Press, Oxford 2004, s. 5.

Zob. D. Ihde Bodies in Technology, University of Minnesota, Minneapolis 2001, s. 3-15.

W. Langland The Vision of Piers Plowman, ed. by A.V.C. Schmidt, 2nd ed., J.M. Dent, London 1995. Polski przekład (Widzenie o Piotrze Oraczu, przeł. i przyp. oraz posł. P. Mroczkowski, Wydawnictwo Literackie, Kraków 1983) obejmuje siedem głównych passusów, bez późniejszej części, przywoływanej w artykule (Vita de Do-Wel, Do-Bel, and Do-Best), dlatego lokalizacje odpowiednich cytatów podajemy w nawiasach zgodnie z angielską edycją [przyp. tłum.]

A. Middleton The Audience and Public of "Piers Plowman", w: Middle English Alternative Poetry and Its Literary Background, ed. by D. Lawton, D.S. Brewer, Woodbridge 1982, s. 119.

1 S. Justice The Genres of "Piers Plowman", „Viator" 1988 No. 19, s. 292.

E. Steiner Reading "Piers Plowman", Cambridge University Press, Cambridge 2013, s. 141. 
poemat raczej literackim niż bezpośrednio instrumentalnym, standardom wartości społecznej i duchowej"23. Wskazane odróżnienie potrzeby praktycznej i literackiej nie może być jednak absolutyzowane.

Rzeczywiście, jak wyjaśnia kolejny passus, to właśnie poprzez łączenie instrumentalnego z literackim w tekstowej uczcie Sumienia gatunek wyłania się jako reguła, dając formę praktyce. Choć niewątpliwie powinniśmy traktować biesiadę tekstów w tym epizodzie jako medytację nad cytatem z Mateusza 4.4: „Nie samym chlebem żyje człowiek, lecz każdym słowem które pochodzi z ust Bożych", to początkowe odniesienie do dworu Sumienia i dworskiej gościnności (XIII.31) przywołuje również uczty ze średniowiecznego romansu, a coraz bardziej dosłowne opisy spożywania i trawienia wnoszą do epizodu element antyklerykalnej satyry. Ten ustęp wciaga czytelników do udziału w wielokształtności gatunkowej praktyki poematu, wpisując trawienie w kolejne konteksty. „Mistrz”, który uczestniczy w uczcie, dworskim gestem składa Pismu niskie ukłony i wyrazy oddania („lowe louted and loveliche to Scripture”). Już same dania sugerują gatunkową różnorodność i społeczną hierarchię romansu. Podawane „dania” są odpowiednie dla tych, którzy je spożywają: ci przy wysokim stole jedzą „głównie przysmaki / Augustyna, Ambrożego i wszystkich czterech Ewangelistów” („sondry metes manye / of Austyn, of Ambrose, of alle the fore Evangelistes", XIII.37-38). Mistrz pożera smakołyki pasujące do dworskiego stołu, włączając „liczne specjały, pasztety i puddingi / flaki, dziką głowiznę i jajka (z pieczoną gęsiną)" ("manye soundry metes, mortrewes and puddynges, / Wombe cloutes, and wilde brawen, and egges (with gece yfryed)", XIII.62-63). Cierpliwość i Will, usadowieni przy bocznym stole, spożywają „kwaśny bochenek” pokutnych psalmów, ale Cierpliwość zauważa: „Tu jest właściwa obsługa ... I książę nie jada lepiej” („Here is propre service ... Ther fareth no prince bettre", XIII.51). Satyryczne w kontekście romansu, stwierdzenie Cierpliwości staje się szczere, jeśli ucztę czytać jako alegorię tekstowej medytacji. Antyklerykalna satyra staje się wyraźniejsza, gdy Will wyśmiewa Mistrza jako „boginię obżarstwa... z jego wielkimi policzkami” („Goddes gloton ... with hise grete chekes", XIII.78).

To właśnie sprawność gatunkowa, jakiej owa scena tekstowego posiłku wymaga od czytelnika, pozwala dobrze zobrazować, jak gatunek nadaje formę praktyce. O ile metafory tekstowej konsumpcji stanowią topos pisarstwa profetycznego i lectio średniowiecznego, to w kontekście pościgu Willa za

23 A. Middleton The Audience and Public of "Piers Plowman"..., s. 111. 
Dowel wyeksponowanie psalmów pokutnych uwydatnia więź formy i doświadczenia, centralną dla znacznej części przednowoczesnego pisarstwa: być odbiorcą tekstów znaczy - konsumować je, być przez nie zmienianym, a wreszcie wcielać je bądź żyć według nich. Jako że scena jest zestawieniem używanych tekstów - ewangelii, psalmów, traktatów teologicznych - to w miniaturze odtwarza gatunkowe nacechowanie całego poematu. Ponadto użycie przez Langlanda wielu kontekstów gatunkowych na potrzeby przedstawianej uczty czyni praktykę tekstową społecznie (w kontekstach romansowych i satyrycznych) i duchowo (w kontekstach pokutnych i alegorycznych) znaczącą.

Hybrydyczność tego epizodu pozwala zauważyć, że gatunek wyłania się na skrzyżowaniu tekstu i praktyki, co widać wyraźnie, jeśli prześledzimy rozwój pojedynczego gatunku, psalmu pokutnego, w obrębie danej sceny. Początkowym nakazem „Agite penitenciam” (XIII.48, Czyńcie pokutę, Mt3,2) Sumienie zachęca Cierpliwość i Wolę do działania i dostarcza gatunkowej ramy dla tekstów, które potem się pojawiają. Nigdy bezpośrednio niezidentyfikowane w tym miejscu jako psalmy pokutne, ujawniają swoją gatunkową przynależność poprzez swoje afektywne oddziaływanie: są tym, co sprawiają. Jak sugeruje Sumienie, po strawieniu owe teksty są życiodajne i mają być wcielane, „trwają jak życie i ciało” ("as lif and lycame may dure”, XIII.50). Jest tu produktywna cykliczność i powtarzalność: w poetyckim przekształceniu Psalmu 31.1-2 Beati quarum zostało stworzone przez Beatus virres. Błogosławieństwo stworzyło błogosławieństwo. Mniej ważny jest „horyzont oczekiwań" śniącego, dotyczący odmian tekstów, które spożyje (pace Jauss) niż ich oddziaływanie na niego. „Sama recytacja psalmów”, przypomina Annie Sutherland, ,jest skutecznym odbyciem pokuty" ${ }^{24}$. W tym sensie - można by powiedzieć - psalmy pokutne pozwalają unaocznić działanie gatunków jako form życia dla średniowiecznych twórców i odbiorców. Innymi słowy, psalmy pokutne wskazują sposób powiązania warunków gatunku ze skutkami jego oddziaływania. Jak pisze Jirsa Curtis, ta scena „określa proces kierowania naszego spojrzenia do wewnątrz za pomocą słów, które wchłaniamy, zmieniając „duchowieństwo” („clergie”) w „naturalną wiedzę” („kynde knowing”), która wiedzie nas do etycznego zachowania i, potencjalnie, do właściwej twórczości poetyckiej"25. Krótko mówiąc, Widzenie o Piotrze Oraczu wykorzystuje psalmy

A. Sutherland Performing the Penitential Psalms, w: Aspects of the Performative in Medieval Culture, ed. by M. Gragnolati, A. Suerbaum, Walter De Gruyter, Berlin 2010, s. 19. 
pokutne w owej scenie jako rozpoznawalnie performatywną odmianę tekstu biblijnego, w której działanie i mówienie, życie i forma tworzą jednolitą praktykę.

Podczas gdy poemat Langlanda ilustruje dynamiczne, rekombinacyjne i aktywne właściwości zestawienia gatunków, Richard Rolle w swoim prologu do Psatterza Angielskiego analizuje kwestie gatunkowe bardziej bezpośrednio. Podkreśla produktywność recytacji psalmów, powodującej wewnętrzną przemianę, „rozpalającej wolę ogniem miłości, wypełniającej nienawiścią bądź smutkiem” ("thaire willes with the fyre of luf, makand thaim hate and brennand withinen") ${ }^{26}$. Psalmy mogą to czynić częściowo dzięki swojemu gatunkowemu zakresowi. Jak pisze Rolle, ich zbiór „mieści w sobie wszystko, co szeroko ujmują inne księgi, czyli mądrość Starego i Nowego Testamentu. Opisano tam nagrody dobrych ludzi, cierpienia chorych, dyscyplinę pokuty, drogę prawego życia, doskonałość świętych mężów” („conteyns all that other books draghes langly: that is, the lare of the ald testament \& of the new. Thare in is discryued the medes of goes men, the pynes of ill men, the disciplyne of penaunce, the waynge in the rightwise lif, the perfection of haly men") itd. ${ }^{27}$ Rolle sądzi, jak wielu średniowiecznych komentatorów, że psalmy stanowią kompendium form, działań i afektu, mikrokosmos treści i form pisarzy Żydowskich i Chrześcijańskich [pisownia oryg. - przyp. red.]. Dalej definiuje on gatunek („księga psalmów [„boke of ympnes”]) w kategoriach czysto doświadczeniowych, afektywnych i performatywnych: „hymn jest miłowaniem Boga pieśnią. Stąd hymn obejmuje trzy rzeczy: umiłowanie Boga, radość serca bądź myśli; czułe rozważanie Bożej miłości. Pieśń jest wielką rozkoszą myślenia o rzeczach wiecznych i nieskończoną radością, wyrażaną głosem miłości” („ympne is lovynge of God with sange. Til an ympne falles thre thynges: louynge of God; ioiynge of heart or thoght; affetuouse thynkynge of Goddis luf. Sange is a gret gladnes of thought of lastand thynge and endless ioy, brestand in voice of lovynge") ${ }^{\mathbf{2 8}}$.

Hymny czy psalmy wyraźnie są dla niego tyleż sposobami bycia, co formami zapisu. Podobnie w Widzeniu, choć spożywanie psalmów ostatecznie

26 The Psalter, or Psalms of David with Certain Canticles, with a Translation and Exposition by Richard Rolle of Hampole, ed. by H.R. Bramley, Clarendon, Oxford 1884, s. 3. Zob. też A. Minnis Medieval Theory of Autorship: Scholastic Literary Attitudes in the Later Middle Ages, Scolar Press, London 1984.

The Psalter, or Psalms of David with Certain Canticles..., s. 4. 
pozwala Willowi „przejść od książek do życia”, uczta tekstów pokutnych poprzedzająca ten ruch dostarcza kolejnej lekcji: że teksty i życie są ze sobą powiązane ${ }^{29}$. Teksty, zwłaszcza performatywne - jak psalmy pokutne - nadają formę zarówno życiu, jak i ożywionej formie. I rzeczywiście, jak sugerują przywoływane prace, jeśli mamy zrozumieć średniowieczne podejście do gatunku, to najlepiej zacząć od samych tekstów, zauważając dzięki nim, co gatunki czynią, jak wcielają „różnorodność praktyk społecznych" ${ }^{\text {”o }}$, kształtując i tworząc doświadczenie. Uczestniczyć w średniowiecznym myśleniu gatunkowym znaczy odrzucać perspektywę, którą Nicolette Zeeman określiła jako „krytyczne uprzywilejowanie dosłowności” ${ }^{31}$, na rzecz badania tego, jak gatunki wyłaniają się w praktyce.

Nie znaczy to, jak czasem sugerowano, by średniowiecze nie miało jasnych ani spójnych teorii gatunku albo żeby „świadomość gatunkowa pozostawała wówczas w zawieszeniu"32. To raczej nasza niezdolność odnalezienia „teorii gatunku" w średniowieczu może być skutkiem postśredniowiecznych oczekiwań co do tego, jak powinna wyglądać taka teoria. Średniowieczne koncepcje gatunku, rozwijane w traktatach retorycznych, często przedstawiają gatunek jako formę życia. Podczas gdy trzy działy retoryki - artes poeticae, artes praedicandi i artes dictaminis - zakładają zestaw gatunkowych rozróżnień (poezja, kazania, proza, listy), a podręczniki często mówią o formie traktatu bądź strukturze (forma lub modus tractatus) oraz jego stylu, sposobie potraktowania sprawy (forma tractandi), to rzadko kiedy mówią o „rodzaju” (genus) czy "gatunku” (species) w sposób, który dałby się łatwo przełożyć na nasze nowoczesne kategorie literackie. Oczywiście takie podręczniki są zwykle raczej normatywne niż teoretyczne, skoncentrowane na pouczeniach dotyczących formalnych zawiłości wywodu bądź figur retorycznych; z tego powodu często zakładano, że ich podstawowym obszarem zainteresowania pozostaje zgodnie z tym, co pisze A.C. Spearing - „literacki styl, rozumiany wyłącznie jako kwestia lokalnego układu słów"33. Choć średniowieczne podręczniki

29

\footnotetext{
T. Lawlor Conscience's Dinner, w: The Endless Knot: Essays on Old and Middle English in Honor of Marie Borroff, ed. by T.M. Tavormina, R.Y. Yeager, D.S. Brewer, Cambridge 1995, s. 91.

A. Butterfield Medieval Genres..., s. 189.

N. Zeeman Imaginative Theory, w: Oxford Twenty-First Century Approaches to Literature..., s. 226.

A. Fowler Kinds of Literature. An Introduction to the Theory of Genres and Modes, Harvard University Press, Cambridge 1982, s. 142.

A.C. Spearing Criticism and Medieval Poetry, Edward Arnold, London 1964, s. 49.
} 
retoryczne czasem przedstawiają gatunek jako układ części ${ }^{34}$ (np. Geoffrey z Vinsauf przekonuje, że literacka inwencja może być rozumiana przez analogię do budowania domu), ostateczna forma budowli jest jednak montażem wielu różnych materiałów. Średniowieczny gatunek zasadniczo pozostaje rekombinacją, ale taki montaż nigdy nie ma jedynie charakteru formalnego czy stylistycznego. Zwykle stanowi raczej odpowiedź na jakąś praktykę kulturową bądź afekt oraz impuls dla nich.

Podczas gdy łacińskie traktaty mogą eksponować formy retoryczne kosztem gatunku, niekiedy definiują go jako połączenie tych form z odpowiednimi uwarunkowaniami i afektywnym oddziaływaniem, podobnie jak ich wernakularne odpowiedniki35. Dla przykładu, retoryczne decorum przypisuje język do określonego stanu życia bądź klasy. Jak sugeruje Poetria Parisiana Jana z Garland: „Pastorali uite conuenit stilus humilis, agricolis mediocris, grauis grauibus personis, que present pastoribus et agicolis”36 ("Niski styl pasuje do życia pasterskiego; styl średni do rolniczego; styl wysoki odpowiada wybitnym postaciom, postawionym ponad pasterzami i rolnikami") ${ }^{37}$. Co więcej, w tych traktatach powiązanie rodzaju literackiego (modus) z praktyką, działaniem, afektem i wykonaniem wskazuje, do jakiego stopnia gatunki i tryby były uznawane za nadające formę doświadczeniu i afektowi ${ }^{38}$. Podobnie jak w wypadku Richarda Rolle łączącego hymny z wytwarzaniem afektu, również inne traktaty - jak prowansalska Doctrina de compondre dictas z XIII wieku

34 Geoffrey of Vinsauf Poetria Nova of Geoffrey of Vinsauf, transl. M. Nims, Pontifical Institute of Medieval Studies, Toronto 1967, s. 16-17.

35 Medieval Grammar and Rhetoric: Language, Arts and Literary Theory, AD 300-1475, ed. by R. Copeland, I. Sluiter, Oxford University Press, Oxford 2009. Wstęp do tej antologii tekstów poświęconych średniowiecznej gramatyce i tekstom retorycznym zawiera bardzo pożyteczny przegląd średniowiecznych ujęć gatunku (zwłaszcza s. 38-47).

36 John of Garland The Parisiana Poetria of John of Garland, ed. and transl. by T. Lawlor, Yale University Press, New Haven 1974, s. 87.

37 Podobnie Dante kojarzy gatunki z trzema poziomami stylu (Dante Alighieri De Vulgari Eloquentia, ed. and transl. by S. Botterill, Cambridge University Press, Cambridge 1996, 2005, s. 57; zob. też J. Orlemanski Genre..., s. 209). Oczywiście średniowieczne traktaty czasem omawiają też i definiują poszczególne gatunki. Np. L'art de dictier E. Deschamps'a (ed. and transl. by D.M. Sinnreich-Levi, Colleagues Press, East Lansing 1994) jest pracą opartą na opisach generycznych, skupiając się na dziewięciu gatunkach wernakularnych.

38 Jak zauważają R. Copeland i I. Sluiter, do XII wieku „tryb (modus) zyskał bardziej precyzyjne powiązanie z literacką formą bądź metodą, jak również z gatunkiem, zarazem zachowując związek z kondycją umysłową i stanem emocjonalnym (Medieval Grammar..., s. 46). 
- wiążą tożsamość gatunkową z motywacją i emocją: „Gatunek lais jest tak zwany, gdyż musi być tworzony z wielką skruchą i poruszeniem serca ku Bogu albo ku rzeczom, o których miałbyś mówić" ${ }^{\prime 39}$. Definiując gatunek skargi, Skarga Marsa Chaucera sugeruje podobny związek formy, afektu i sprawy: „wymogiem skargi jest dobry powód jej złożenia. Jeśli zostanie to zrobione umiejętnie, powinno wzbudzić litośc” („The order of compleynt requireth skylfully / That yf a wight shal pleyne pitously, / Ther mot be cause wherefore that men pleyne", w. 155-157 ${ }^{40}$.

Większość odniesień do gatunku literackiego w tekstach wernakularnych Europy późnego średniowiecza nie zawiera jednak tak bezpośrednich omówień. Jak pokazuje większość autorów, wczesne myślenie gatunkowe przejawia się raczej implicite w strukturze, stylu, nawiązaniach i użyciu zapisów. Nawet wernakularne prologi, te bogate skarbnice teoretycznoliterackie, które często wprowadzają treści retoryczne i dydaktyczne do lokalnego języka, zwykle odnoszą się jedynie pośrednio do gatunkowych zobowiązań danego dzieła ${ }^{41}$. Choć większość prac dotyczących prologów w takich utworach skupia się głównie na przedstawieniu przekładu i kształtowaniu literackiego autorytetu, mogą one dać nam również pewne wyobrażenie o tym, jak ówczesne pisarstwo traktowało gatunek, co nasuwają choćby wstępne komentarze Rolle'a o hymnach. Wiele z tych prologów sugeruje, jak gatunek wyłania się w praktyce i odbiorze, podkreślając związek formy i życia. Dla przykładu, we wprowadzeniu do Legendys of Hooly Wummen z połowy XV wieku Osbern Bokenham snuje rozważania nad forma tractandi i forma tractatus, wedle których początek każdego dzieła powinien wyjaśniać „co" $i$ „dlaczego" danego tekstu ${ }^{42}$.

39 The "Razos de Trobar" of Raimon Vidal and Associated Texts, ed. by J.H. Marshall, Oxford University Press, London 1972, s. 97.

G. Chaucer Complaint of Mars, w: The Riverside Chaucer, ed. by L.D. Benson, Houghton Mifflin, Boston 1987, s. 645 .

Antologie takie jak The Idea of the Vernacula: An Anthology of Middle English LiteraryTheory, 1280-1520, ed. by J. Wogan Browne i in., Pennsylvania State University Press, University Park 1999, w znacznej mierze przyczyniły się do uprzystępnienia teoretycznego dorobku takich prologów dla nowoczesnych czytelników. Dodatkowe omówienie ważności wernakularnych prologów - I.R. Johnson i in. Vernacular literary consciousness C. 1100-C. 1500, w: The Cambridge History of Literary Criticism, vol. 2: The Middle Ages, ed. by A. Minnis, I. Johnson, Cambridge University Press, Cambridge 1989, zwł. s. 423.

Por. John of Garland Parisiana Poetria of John of Garland, ed. and transl. by T. Lawlor, Yale University Press, New Haven 1974: „Qvinque sunt inquerenda in principio huius opusculi: scilicet material, intention auctoris, vtilitas audentis, cui parti philosophie supponatur, quis sit modus 
Trzy rzeczy jego zdaniem „należą do tego, «co»: autor, sprawa i przyczyna formalna” ("Aucto, matere and forme ordinat”) ${ }^{43}$. Jednak objaśniając „sposób postępowania” („form of procedyng”), Bokenham wyraźnie odrzuca techniki promowane w traktatach retorycznych i twierdzi, że choć jego ujęcie jest nieco toporne, to „w przejrzysty sposób opowiada legendę, co usłyszą ci, którzy zdecydują się poświęcić mu swą uwagę” ("pleynly declaryth hyr legend, / As they shul heryn wych lyst attende” ${ }^{44}$. Zamiast postępować „według zasad sztucznego porządku... zgodnie z naukami przemyślnego urzędnika Golfryda z Anglii” („the form of procedyng artificial... After he scole of the crafty clerk / Galfryd of ynglond") Bokenham interesuje się raczej tym,jak przekład mógłby „poruszyć różne afekta” („excite mennys affeccyoun”) niż „zmyślną robotą” („crafty werk") poetyckiego upiększenia ${ }^{45}$. Gatunek żywota bądź legendy jest tu rozpoznawany nie tyle poprzez swoją formę bądź treść, ile raczej poprzez warunki wytwarzania (religijne oddanie Bokenhama i chęć zadowolenia mecenasa, patrona) oraz oczekiwany rezultat (poruszenie afektów).

Jak pokazuje ten oraz inne teksty wernakularne i jak dowodzi wiele przywołanych prac, nie można oddzielić średniowiecznych koncepcji gatunku od doświadczenia, wykonania (performance), odbioru. Ponadto omawiać odbiór znaczy nie tylko myśleć o tym, co średniowieczni czytelnicy wnosili do czytanych tekstów albo mówić o Jaussowskim „horyzoncie oczekiwań”. Jak widzieliśmy w obrazie tekstowej konsumpcji podczas uczty Sumienia, gatunki są często definiowane raczej poprzez efekty ich działania, przez afekt, doświadczenie bądź przez „światy życia”, jakie tworzą. Zwrot ku afektywnej i kognitywnej reakcji może, jak w swoim eseju sugeruje Eleanor Johnson ${ }^{46}$, otworzyć nowe perspektywy szerszego ujmowania gatunku, ponieważ „nowe i produktywne pogrupowania średniowiecznych tekstów wyłaniają się, gdy pojmujemy gatunek jako formę zdefiniowaną przez dążenie do wytworzenia określonego stanu umysłu i afektu". Jeśli więc nawet średniowieczna teoria rozwija i ilustruje określone taksonomie czy zalecenia gatunkowe, to zarazem

agendi” (s. 2-3: „Pięć kwestii dotyczących tej krótkiej pracy należy omówić na początku: przedmiot sprawy, cel autora, pożytek dla publiczności, odpowiedni obszar wiedzy, metoda").

O. Bokenham Legendys of Hooly Wummen, ed. by M. Serjeantson, Oxford University Press, London 1938, s. 19-20.

Tamże, s. 81-82.

Tamże, s. 83, 85-86, 98, 128. 
przekracza je, eksponując związek między tekstem, kontekstem i audytorium. Gatunek jest tym, co powstaje w praktykowaniu owych form, zarówno w tworzeniu, jak i odbiorze.

Jeśli wiele średniowiecznych traktatów pośrednio definiuje gatunek jako formę życia, poprzez wyobrażenie tekstów wyłaniających się z wzajemnego oddziaływania teorii i praktyki, to pewne oznaki taksonomicznego podejścia, które cechują postśredniowieczną genologię, zaczęły się też pojawiać w późnym średniowieczu. Do XV wieku francuskie „Sztuki Drugiej Retoryki", jak L'art de dictier Deschampes'a, próbowały zarówno definiować, jak i modelować główne gatunki i formy ${ }^{47}$. Chociaż ów zwrot ku gatunkowym taksonomiom oznacza pewne odejście od wcześniejszych ujęć, przygotowuje też grunt, na którym gatunki mogły być definiowane jako czysto estetyczne bądź formalne, oddalone od doświadczenia i wykonania, a także traktowane raczej jako statyczne niż dynamiczne układy. W pełni taksonomiczny system pojawia się wraz z neoklasycznymi traktatami z XVI i XVII wieku, kiedy sam gatunek staje się „zasadą organizacyjną i główną troską w wielu renesansowych prezentacjach poetyki"48. Obrona poezji (Defense of Poesy) Sir Philipa Sidneya wymienia np. osiem „znakomitych" gatunków poetyckich: heroiczny, liryczny, tragiczny, komiczny, satyryczny, jambiczny, elegijny i pastoralny ${ }^{49}$. Postoświeceniowe modele estetyki, które zachęcały do kontemplowania autonomicznych przedmiotów estetycznych, dały impuls nowocześniejszej teorii gatunku. W ślad za wpływową krytyką estetyczną takich filozofów jak Hegel gatunki literackie przyporządkowano do trzech rodzajów: liryki, epiki i dramatu.

O ile jednak teoria gatunku po średniowieczu często eksponowała abstrakcyjne prawa taksonomii, to sugerujemy, że ustalanie tych praw implicite zmagało się z gatunkiem jako formą życia. Wiele takich teorii skupia się wokół skrzyżowania tekstowych odmian i świata życia, zwłaszcza w jego czasowych, przestrzennych $i$,wirtualnych" wymiarach/aspektach. Weźmy np. pod uwagę zwyczajową definicję gatunku jako „instytucji”, która istnieje, jak to ujmują Rene Wellek i Austin Warren:

Zob. The Cambridge History of Literary Criticism..., s. 455; A. Hiatt Genre Without System, w: Oxford Twenty-First Century Approaches to Literature..., s. 279. 
nie w ten sam sposób co zwierzę ani nawet jak budynek kaplicy, biblioteki czy gmach parlamentu, ale tak, jak istnieje instytucja. W obrębie istniejących instytucji można działać i wyrażać w nich siebie, można tworzyć nowe albo działać w miarę możności, stroniąc od wszelkich organizacji czy obrządków; można także przyłączyć się do instytucji, ale później ją przekształcić. ${ }^{\mathbf{5 0}}$

Rozwinięcie tej metafory przypomina nam, że instytucje zajmują fizyczną przestrzeń („budynek kaplicy, biblioteki czy gmach parlamentu”) i zmieniają się z upływem czasu („przekształcany” przez swych członków), nawet jeśli metafora sugeruje pewien poziom ponadhistorycznej trwałościs1.

Jak sugeruje metafora „instytucji”, powstanie nowoczesnej teorii gatunku jest związane z historiografią. Dla Hegla i jego współczesnych trzy rodzaje (genres) epickiej, lirycznej i dramatycznej poezji powstały w różnych epokach $^{52}$. Poezja epicka rozkwita w - jak to określa Hegel - „heroicznych” warunkach historycznych, określonych przez rodowe i wspólnotowe struktury powiązań, które jeszcze nie mają charakteru narodowych ${ }^{53}$. Poezja liryczna rozwija się w takich warunkach, „które wytworzyły już mniej więcej gotowy system stosunków życiowych, gdyż w takich dopiero czasach jednostka ludzka, przeciwstawiając się światu zewnętrznemu kieruje się refleksją ku sobie, i wycofując się ze świata zewnętrznego, zamyka się w swoim wnętrzu jako samoistna, odczuwająca i wyobrażająca całość", a poezja dramatyczna wymaga powstania „zasady indywidualności"54 dla rozwinięcia swojej dialektyki wewnętrznej świadomości i zewnętrznej rzeczywistości. Jednak wszystkie trzy rodzaje poezji przechodzą przez, jak to określa Hegel, trzy epoki estetyczne symboliczną, klasyczną i romantyczną - którym w przybliżeniu odpowiada prehellenistyczna bądź „prymitywna” historia, Grecja i Rzymskie Imperium

50 R. Wellek, A. Warren Teoria Literatury, przekł. pod red. i z posł. M. Żurowskiego, Warszawa 1976, S. 306-307.

51 Ta metafora jest używana przez wielu innych teoretyków gatunku, jak m.in. F. Jameson czy T. Todorov. Zob. D. Fishelov Metaphors of Genre: The Role of Analogies in Genre Theory, PennsyIvania State University Press, University Park 1993, s. 85-117.

52 Omówienie, jak ten romantyczny trójdzielny podział gatunków pojawia się jako błędne odczytanie klasycznej teorii gatunków, zob. G. Genette The Architext: An Introduction, transl. ) E. Lewin, University of California Press, Berkeley 1992. G.W.F. Hegel Estetyka, przeł. J. Grabowski, A. Landman, t. 3, PWN, Warszawa 1967, s. 408. 
oraz nowożytność. Northrop Frye identyfikuje cztery fabuły („mythoi”), strukturyzujące dzieła literackie: komedię, tragedię, romans i satyrę, które odnoszą się do czasowych zjawisk pór roku. Te fabuły mają potencjał gatunkowy, co widać w pracy historyka Haydena White'a, który wykorzystał je do opisania form narracji historycznych. W taksonomii White'a historycy i filozofowie XIX wieku stosowali te cztery odmiany w swoich fabularyzacjach europejskiej historii. Podobnie jak w wypadku metafory gatunku jako „instytucji”, pozornie synchroniczne fabuły (mythoi, których analogia do pór roku sugeruje powtarzalność) mają diachroniczną siłę, nadając wzorzec historycznej zmianie.

Krytyki tego ogólnego, makrologicznego schematu zbliżyły się - choć bez bezpośredniej artykulacji - do idei gatunku jako formy życia, wskutek skupienia się na lokalnej i mikrologicznej naturze form generycznych. Dialektyczna krytyka Frye'a, podjęta przez Frederica Jamesona, koncentruje się na złożonej czasowości gatunku, z gatunkiem jako „funkcją mediacyjną” między „immanentną analizą formalną pojedynczego tekstu” i „bliźniaczo diachroniczną perspektywą historii form i ewolucji życia społecznego" 55 . Równie ważne dla gatunku w literackiej strukturze tekstu są „modalności” wypowiedzi, lokalnie wcielone w formy językowe, które przywołują bądź oczyszczają gatunki, wydobywając ich wspólną stylistykę. Te modalności wydają się synchroniczne, zachowując trwałość, nawet kiedy rozpadają się instytucje, które wytworzyły szersze kategorie gatunkowe, ale właściwie one również podlegają historycznej zmianie ${ }^{56}$. Bachtin postrzegał takie historyczne zmiany w retoryce jako nieodłączne od przemiany tego, co określał pojęciem "gatunków mowy", obejmującym wszystkie formy użycia języka w mowie i piśmie ${ }^{57}$. W miarę jak badania gatunkowe wychodzą poza tekst konwencjonalnie „literacki”, część refleksji najbardziej uwrażliwionej na specyfikę zlokalizowanych praktyk pojawia się w studiach retorycznych i medioznawczych. Retoryczne interpretacje gatunku ujmują go jako rodzaj „działania społecznego", wnoszącego zarówno własne ideologie, jak i potencjał społecznej zmiany ${ }^{58}$. Historia filmu pokazuje, że ciągła negocjacja między zlokalizowanymi podgatunkami („film kolejowy”,,headline picture”) i szerszymi odmianami („western”, ,biografia”) strukturyzuje dwa tryby określające gatunek, które Rick Altman określa jako

55 F. Jameson The Political Unconscious..., s. 105.

56 A. Fowler Kinds of Literature..., S. 106-129.

M. Bachtin Problem gatunków mowy..., s. 65.

58 Zob. C. Miller Genre as Social Action...; The Rhetoric and Ideology of Genre... 
"grę krytyka" i „grę producenta"59. Podczas gdy krytycy definiują gatunek jako wsteczny derywat wydobyty z określonych okazów, biorąc np. pod uwagę paradygmatyczny „western” i tworząc jego historię poprzez przekopywanie zasobów filmografii, to producenci angażują się w pętlę zwrotnej reakcji sukcesu komercyjnego i modyfikują mikrogatunkowe cechy filmów, które ostatnio odniosły sukces, aż połączenie stapia się w krytycznie spójny gatunek.

O ile czasowy wymiar świata życia napędzał rozwój postoświeceniowej teorii gatunku, to przestrzeń odgrywała zdecydowanie mniej znaczącą rolę w owej koncepcji. Hegel odrzuca wagę przestrzeni geograficznej dla gatunku epickiego:

Np. geografia rodzinnego kraju jest jednym z elementów narodowości; ale jeśli nie nadaje ona narodowi właściwego mu, specyficznego charakteru, wówczas jakieś inne, bardziej oddalone otoczenie naturalne może (o ile tylko nie jest sprzeczne z charakterem narodowym) albo nie wywierać szkodliwego wpływu, albo nawet mieć w sobie coś pociągającego dla wyobraźni. ${ }^{60}$

Przestrzenne cechy materialnego tekstu dostarczają okazji - według Crocego - jedynego dobrego zastosowania dla gatunku: ustawienia książek na półkach bibliotecznych ${ }^{61}$. Przestrzenna metafora zyskała jednak szerokie zastosowanie w genologii, od "horyzontu oczekiwań" Jaussa po ideę "granic" gatunkowych (które mogą być bezprawnie „przekraczane”). Ruchliwość i skala, implikowane przez ostatnią metaforę, prowadzą do wyobrażenia „mapy” gatunkowej, przecinanej przez rekurencyjne bądź nielegalne trasy. Jej sieci relacyjne oferują ruchome skale, które mogą być przedstawiane za pomocą geometrii fraktalnej, utrzymującej „teksturę” gatunkową przez dopasowywanie małych i dużych gatunków ${ }^{62}$. Dla przykładu, spośród wspominanych autorów Emily Steiner i Nancy Bradbury zajmują się dialektyką skali gatunkowej, czyli tym, jak „krótka” forma, w której ogrom materii warunkuje i wytwarza strukturę gatunkową, zmierza ku zwięzłości liryki, a z kolei dla odmiany - jak

59 R. Altman Film/genre, BFI Publishing, London 1999.

60 G.W.F. Hegel Estetyka..., s. 415-416.

61 B. Croce Aesthetic..., s. 38.

62 W. Dimock Through Other Continents: American Literature Across Deep Time, Princeton University Press, Princeton 2006, s. 73-106; W. Dimock, B. Robbins Remapping Genre, "PMLA" 2007 No. 122.5 . 
mikrogatunek przysłowia osadza się w większych strukturach gatunkowych i uczestniczy w kształtowaniu ich spójności.

Świat życia zawiera też wirtualne przestrzenie, których proteuszowa geometria dostarcza nowych modeli dla refleksji genologicznej. Obejmują one model gatunku jako pulpitu - w którym „użytkownik” (czytelnik/autor) może do woli „przełączać”, „sortować” lub „skanować” gatunki - bądź jako bazy danych zorientowanej na wyszukiwanie czy też pustej przestrzeni, opuszczonej przez duchy, w gatunkowej maszynie. Jako forma życia gatunek jest zarazem wirtualny i zjawiskowy, oferując sposoby życia poprzez tekst, które „nigdy nie są po prostu faktami, ale zawsze i przede wszystkim możliwościami [wyróż. oryg.] życia" - albo tekstów ${ }^{63}$. Jane Gilbert w przywołanym wcześniej eseju o „otwartych” i „zamkniętych” trybach lektury gestes d'Alexandre pokazuje, jak gatunek kreuje taką wirtualną przestrzeń potencjalności.

Razem wzięte przywołane prace przekonują, że średniowieczne gatunki oraz koncepcje mogłyby wnieść poprawki bądź alternatywne ujęcia do nowoczesnej refleksji genologicznej, jako że podważają lub komplikują opozycje, na których często opiera się teoria gatunku: instrumentalne vs. estetyczne, innowacyjne vs. konwencjonalne, czysta forma vs. hybryda, czytane vs. wykonane. Pozwalają także dostrzec, w jaki sposób gatunek jest zawsze implicite obecny w średniowiecznych praktykach tekstowych. Jako forma życia gatunek wiąże tekst z doświadczeniem, nie jako normatywne „prawo”, ale jako struktura życia. Porowate granice między tekstami „literackimi” i „dydaktycznymi” badane przez wspominanych tu autorów odzwierciedlają większe poczucie płynności w średniowiecznych gatunkach i rodzajach, których podziały, przepisy i konwencje zyskują określoną postać w określonym środowisku życiowym tekstu i praktyki. Ten model gatunku stawia opór totalizacji bez uciekania się do struktury, będąc nie tyle alienującym „prawem”, ile raczej twórczą „regułą”.Jak zauważa Agamben w kontekście życia benedyktyńskich zakonników, gatunek jest formalną przestrzenią potencjalności, która czyni teksty nie tyle „regularnymi”, ile „żywotnymi”64. Średniowieczne gatunki i ówczesna refleksja genologiczna zachowują żywotność, która wywiera nacisk na historyczne granice i tworzy modele, przekraczające macierzyste konteksty i wyrażające formy życia, niosąc też implikacje dla postśredniowiecznych tekstów oraz ich praktyk.

Przełożył Grzegorz Grochowski

63 G. Agamben Means Without Ends..., s. 4.

64 G. Agamben Highest Poverty..., s. 26. 


\section{Abstract}

\section{Ingrid Nelson}

AMHERST COLLEGE

\section{Shannon Gayk}

INDIANA UNIVERSITY

Genre as Form-of-Life

This essay argues for the importance of re-evaluating the medieval genres and genre theories. Drawing on Giorgio Agamben's notion of "form-of-life," based on monastic practice, the essay considers how early writing represents genre as intrinsically linked with experience and practice. In medieval genres, taxonomies, prescriptions, and conventions take shape within a lifeworld of text and practice. And, for this reason, early genre and genre theory complicate some of the binaries on which later genre theory sometimes relies: the instrumental and the aesthetic, the innovative and the conventional, the pure form and the hybrid, the read and the performed.

\section{Keywords}

genre, form-of-life, vernacular literature, genre studies, middle ages 